\title{
Advances in understanding Giardia: determinants and mechanisms of chronic sequelae
} Luther A. Bartelt ${ }^{1 *}$ and R. Balfour Sartor ${ }^{2}$

\author{
Addresses: ${ }^{1}$ Division of Infectious Diseases and International Health, University of Virginia, Box 801340, Charlottesville, VA 22908, USA; \\ ${ }^{2}$ Division of Gastroenterology, Center for Gastrointestinal Biology and Disease, University of North Carolina at Chapel Hill, \\ Campus Box 7032, Chapel Hill, NC 27599-7032, USA \\ * Corresponding author: Luther A. Bartelt (lab2za@virginia.edu) \\ Fl000Prime Reports 2015, 7:62 (doi:10.12703/P7-62) \\ All Fl000Prime Reports articles are distributed under the terms of the Creative Commons Attribution-Non Commercial License \\ (http://creativecommons.org/licenses/by-nc/3.0/legalcode), which permits non-commercial use, distribution, and reproduction in any medium, \\ provided the original work is properly cited. \\ The electronic version of this article is the complete one and can be found at: http://f1000.com/prime/reports/b/7/62
}

\begin{abstract}
Giardia lamblia is a flagellated protozoan that is the most common cause of intestinal parasitic infection in children living in resource-limited settings. The pathogenicity of Giardia has been debated since the parasite was first identified, and clinical outcomes vary across studies. Among recent perplexing findings are diametrically opposed associations between Giardia and acute versus persistent diarrhea and a poorly understood potential for long-term sequelae, including impaired child growth and cognitive development. The mechanisms driving these protean clinical outcomes remain elusive, but recent advances suggest that variability in Giardia strains, host nutritional status, the composition of microbiota, co-infecting enteropathogens, host genetically determined mucosal immune responses, and immune modulation by Giardia are all relevant factors influencing disease manifestations after Giardia infection.
\end{abstract}

\section{Introduction}

Giardia lamblia (also known as G. duodenalis and G. intestinalis) is the most common and oftentimes earliest parasitic infection in children and the most common cause of diarrhea in travelers presenting to clinics [1-4]. Owing to an estimated 280 million infections every year $[5,6]$, nearly universal infection among children living in resource-limited regions worldwide $[6,7]$, the potential for persistent and recurrent infections with an average duration of Giardia carriage of 6.3 months among children in some populations [2], and limited affordable effective therapeutic options $[8,9]$, the World Health Organization (WHO) considers Giardia a neglected tropical disease $[10,11]$. Because the parasite is environmentally ubiquitous, can persist for prolonged periods in the environment as hardy cysts, is capable of propagating through both anthroponotic [12] and zoonotic [13-19] reservoirs, and has an infectious dose as low as 10 cysts [20], Giardia exposures can also occur in resource-abundant settings [21-25]. In the United States, for example, infection is characterized by seasonal and recreational waterborne transmission $[22,23]$ and clustered daycare outbreaks [26]. Transmission through food sources, such as leafy green vegetables and culinary bivalves harboring G. lamblia shed from coastal and marine life [27-29], is also possible.

Anton van Leeuwenhoek first identified Giardia in his own diarrheal stool in 1681, but the parasite did not become an officially WHO-recognized pathogen until 1981. Even after Theodore Nash and colleagues [30] fulfilled Robert Koch's postulates in human volunteers in 1987 [20], disease attributable to Giardia was debated. Complicating this clinical equipoise is the predominance of apparently asymptomatic hosts and as-of-yet elusive mechanisms explaining how some individuals develop the characteristic giardiasis syndrome: abdominal cramping and bloating, malabsorptive diarrhea (steatorrhea), and weight loss [18]. Furthermore, for unclear reasons, chronic sequelae, including post-infectious irritable bowel syndrome, chronic fatigue [31], malnutrition [32], cognitive impairment [33], and extra-intestinal manifestations (such as food allergy, urticaria, reactive arthritis, and inflammatory ocular manifestations), can develop and 
Figure I. The clinical spectrum of Giardia infection

Asymptomatic

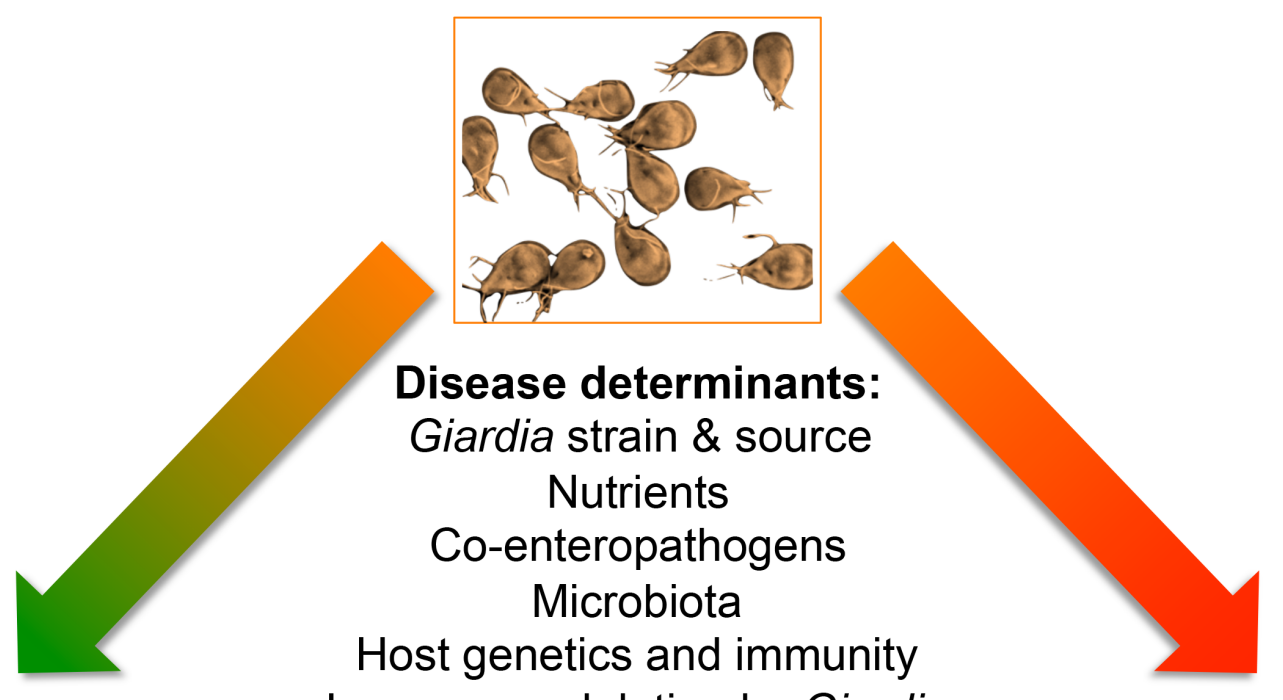

\section{Protection against acute diarrhea}

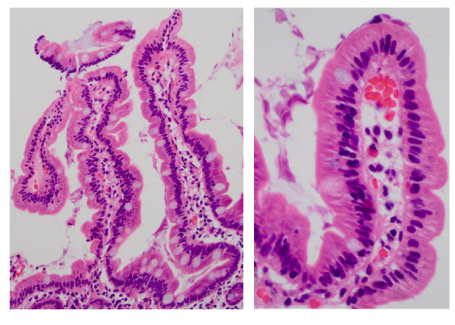

Normal

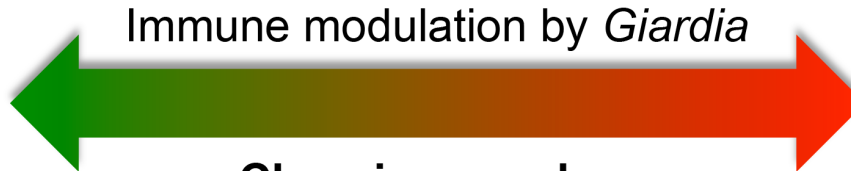

Chronic sequelae:

Irritable Bowel Syndrome
Growth faltering/Failure to Thrive
Chronic Fatigue
Cognitive impairment
Post-infectious arthritis
Uveitis, retinal lesions
Urticaria

\section{Persistent diarrhea \&} malabsorption

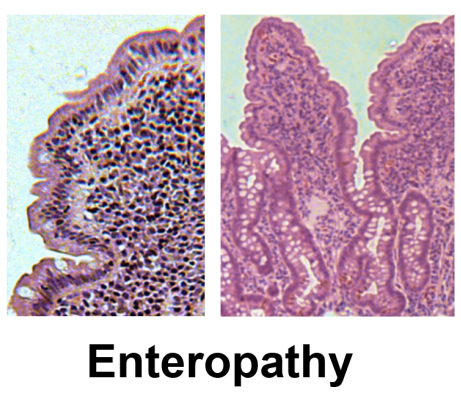

The majority of individuals infected with Giardia are asymptomatic. Within the diarrhea spectrum of disease, Giardia paradoxically associates with both protection against acute diarrhea and persistent diarrhea with or without malabsorption and enteropathy. Hypothesized determinants of how disease will manifest on this spectrum include the virulence of the infecting strain(s) of Giardia, host nutritional intake, co-infecting enteropathogens, the composition and function of resident microbiota, immune modulation by Giardia, and host genetics and immunity. Changes in these dynamic variables may further skew disease manifestation. Histological changes vary from normal histopathology (bottom left) to villus shortening and chronic inflammatory infiltrate (enteropathy) (bottom right). Chronic sequelae associated with giardiasis include irritable bowel syndrome, chronic fatigue, childhood growth faltering, failure to thrive, cognitive impairment, and extra-intestinal manifestations presumed to be related to immunologic phenomena (reactive arthritis, inflammatory ocular manifestations, and urticaria) that are not necessarily dependent on severity of diarrheal manifestations and may persist even beyond detection of the parasite. Giardia trophozoite image courtesy of Joel Mancuso and Scott Dawson. Images of small-bowel biopsies from patients with giardiasis showing normal (left) and abnormal (right) histopathology courtesy of Leana Guerin (left) and Jörg-Dieter Schulzke (right).

possibly persist beyond detectable parasite shedding (Figure 1).

Global efforts to improve child health in resourcelimited settings situate Giardia infections amidst the broader context of childhood malnutrition, a multitude of diverse and frequent enteric pathogen exposures [34], and new understandings of the role of environmental enteropathy (a form of chronic gastrointestinal dysfunction and inflammation possibly inclusive of the previously termed clinical condition 'tropical sprue') $[11,35]$ and microbiota [36] on childhood development and growth. The most recent analyses, equipped with more rigorous surveillance methods and more sensitive molecular diagnostics [37-39], have not only reiterated the wide range of variability in pediatric Giardia infection 
outcomes seen in prior studies [3] but unveiled a much greater burden of exposure than estimates based on microscopic techniques $[39,40]$. These and other studies have raised provocative considerations, including the potential for Giardia to be protective against acute diarrhea [41-43].

In light of the incompletely understood pathology attributable to Giardia infection, recent advances in parasite and gastrointestinal biology hope to clarify how and when Giardia causes disease. These advances address fundamental questions regarding how Giardia interacts within the complex ecology of microbial, nutritional, and host factors within the small intestine, the determinants of host susceptibility, and whether and how host inflammation contributes to pathogenesis (Figure 2).

\section{Endemic pediatric giardiasis equipoise}

In 1971, after charting weights of children in Guatemala, Leonardo J. Mata reported an association between arrested growth and frequent episodes of diarrhea [44]. A follow-up analysis of these children associated increased duration and frequency of Giardia episodes with a greater detrimental growth impact [45]. Since then, several studies have attempted to demonstrate how early Giardia infections promote diarrhea and developmental shortfalls. A 2012 meta-analysis found that, although Giardia infection was associated with persistent diarrhea (>14 days; odds ratio [OR] 3.2, 95\% confidence interval [CI] 1.50-6.76; $P<0.001)$, there was a negative association with moderate-severe acute diarrhea (OR 0.6, 95\% CI 0.38-0.95; $P<0.03$ ) [3]. Subsequently, the Global Enteric Multicenter Study identified a similar paradox [41]. This finding was consistent regardless of diagnostic modality and quantitative burden in stool specimens [39]. Other prospective cohort studies in Tanzania [42] and Iran [43] also demonstrated a delay in first episode of diarrhea in children who were positive for Giardia at enrollment. Elsewhere, Giardia is positively associated with acute diarrhea [46], and younger children may be at greater risk for acute diarrhea with Giardia infection [3].

Associations between Giardia and childhood growth and developmental shortfalls have also been variable. Stunting (low height-for-age $\mathrm{z}$ score) has been documented in Brazil [47], Colombia [48], and Ecuador [49]; poor intestinal permeability has been seen in Nepali children [50], growth impairment in Rwandan children [51], wasting in Malaysia [32] and India [52], and low weight-for-age and height-for-age in Brazilian children with persistent symptoms [53,54]. In addition, cognitive impairment has been documented in children up to seven years after Giardia infection independent of physical growth [33]. Other equally valid studies, however, have shown no significant influence on developmental outcome or nutritional status [3,55-57]. The Malnutrition and Enteric Disease Study, to date the most comprehensive longitudinal cohort study aimed at determining environmental, nutritional, and enteric pathogenic influences on childhood development, is ongoing and will offer the most complete opportunity to ascribe associations between Giardia, growth, and gastrointestinal dysfunction [58]. There have been no randomized controlled trials evaluating the developmental impact of specific anti-giardial therapies in malnourished children. However, bovine fecal lactoferrin supplementation simultaneously decreases Giardia colonization and promotes child growth [59].

Whether Giardia infection initiates or promotes childhood malnutrition has major implications for the nearly $20 \%$ of undernourished children worldwide [58]. Malnutrition substantially increases mortality and morbidities to both infectious and non-infectious conditions, and undernourished children may not demonstrate expected restorative gains with nutritional supplementation. Indeed, protein energy malnutrition [60], zinc deficiency, and vitamin A deficiency [61] may increase susceptibility to Giardia. Conversely, Giardia infection may reduce supplemental zinc uptake [62-64] and influence dose response to vitamin A supplementation [65]. Further confounding nutritional determinants in Giardia outcomes are the findings in a study of multi-nutrient therapy for childhood diarrhea that Giardia-infected subjects in the placebo arm were protected against diarrhea but that Giardia-infected subjects in the multi-nutrient intervention arm were not [42]. Proposed mechanisms explaining such paradoxical findings suggest that specific nutrients may promote Giardia growth or otherwise directly mediate Giardia pathogenicity, alter host microbiota and other defenses, or interfere with the parasite's influence on coenteropathogens and host immune responses.

\section{Determining how Giardia causes disease}

Infection with Giardia occurs after ingestion of the environmental cyst stage of the parasite, which upon gastric passage excysts to release two trophozoites into the less acidic and bile-enriched environment of the upper small bowel. Trophozoites adhere to epithelial cells and replicate but typically do not invade the intestinal mucosa or cause ulceration $[6,66]$. If symptoms develop, onset typically begins after a 6 - to 15 -day incubation period that oftentimes precedes detection of parasites in stool [5]. The type of diarrhea experienced in giardiasis is classically greasy and foul-smelling (steatorrhea) with findings of malabsorption of vitamins A and B12, d-xylose, iron, and zinc $[3,67-69]$ as well as lactase deficiency in $20-40 \%$ of 
Figure 2. Proposed determinants and mechanisms of Giardia infection outcomes

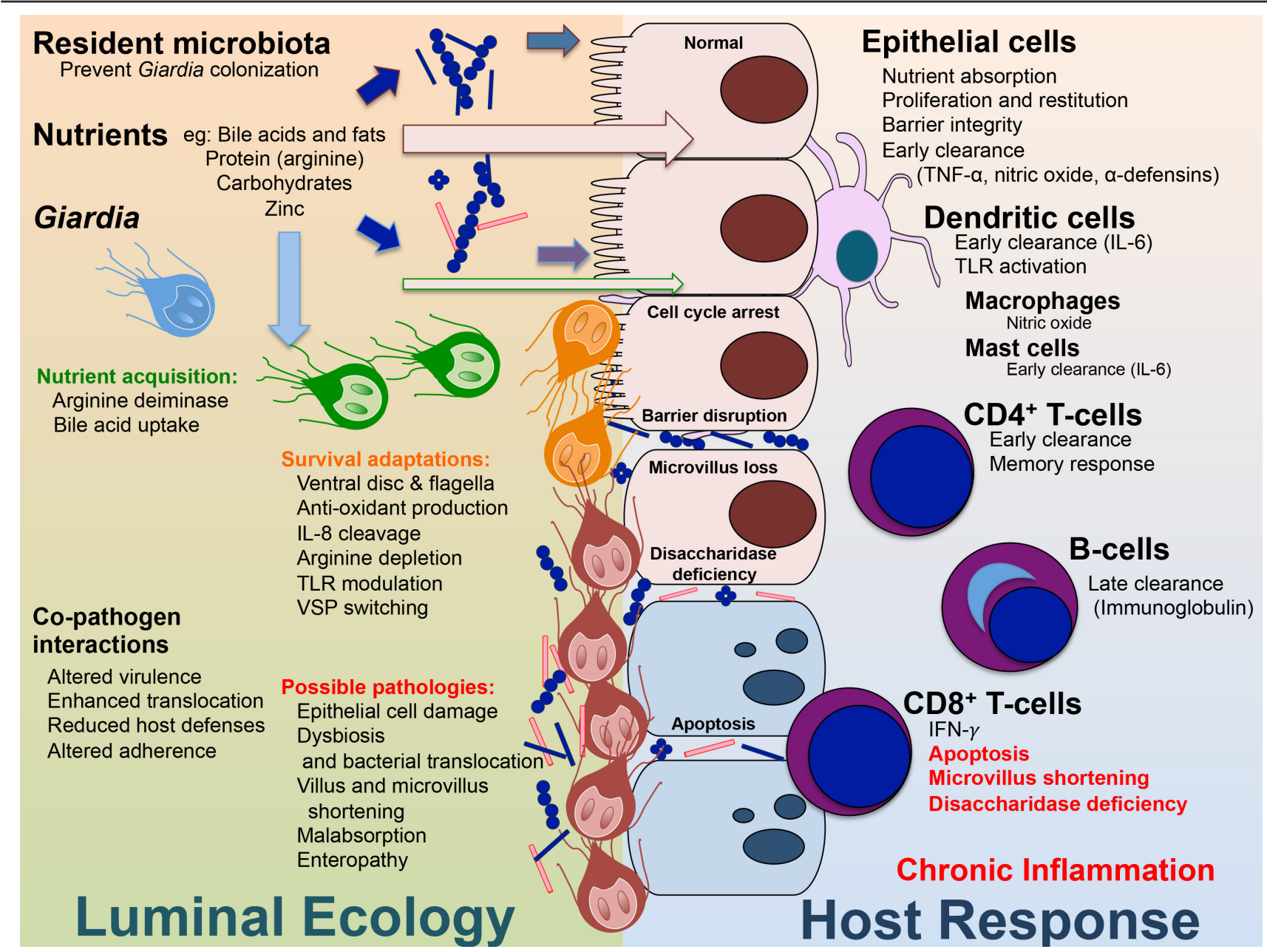

Complex interactions between microbiota, nutrients, Giardia strain, co-enteropathogens, and host molecular responses in the luminal and mucosal environment likely influence Giardia infectivity and disease outcomes. (Left) Resident microbiota maintain resiliency to colonization. Giardia uses, and potentially sequesters, nutrients such as bile, arginine, and zinc in order to survive, replicate, and evade microbiota and host defenses. Flagella and the ventral disc are structures of trophozoites that aid attachment and adherence to intestinal epithelial cells (IECs). Giardia uses functional virulence factors to evade host inflammatory responses through antioxidant production, cleavage of interleukin-8 (IL-8), arginine depletion via arginine deiminase (ADI), and shifts in variant surface protein (VSP) expression. Effects of Giardia on epithelial cells (that is cell-cycle arrest, impaired proliferation, tight-junction disruption, and apoptosis) may be strain dependent and either direct or indirect. Subsequent changes in nutrient availability, microbiota composition, inflammatory defenses, and epithelial cell pathogen attachment sites may secondarily alter disease manifestations of co-infecting enteropathogens. (Right) Redundant mucosal immune responses promote Giardia clearance early (epithelial cell nutrient uptake for host fitness, barrier function maintenance, and pro-inflammatory molecules; IL-6 derived from dendritic cells and mast cells; and $\mathrm{CD} 4^{+}$and $\mathrm{CD} 8^{+} \mathrm{T}$ cells) and late in disease (CD4 ${ }^{+} \mathrm{T}$-cell memory and B cells). CD4 ${ }^{+} \mathrm{T}$ cells induce memory responses but also contribute to chronic inflammation and may promote disaccharidase deficiency. $C D 8^{+} \mathrm{T}$ cells mediate apoptosis, microvillus shortening, and disaccharidase deficiency. Epithelial cell damage may persist beyond parasite clearance, allowing sustained translocation of microbiota and microbial products. The altered mucosal homeostasis and inflammation (enteropathy) and microbiota composition may further impede nutrient uptake and contribute to prolonged sequelae, including impaired growth and cognitive development.

symptomatic cases [70]. Histological biopsies of smallbowel mucosa are often without any apparent abnormality [71]. However, increased lymphocytic infiltrates and decreased villus-to-crypt ratios have been described in some children [72], and inflammation has been reported in some adults with either acute [73] or chronic [74] infection.
Experimental as well as clinical observations indicate that the primary cause of diarrhea in giardiasis is malabsorption and that hypersecretion during chronic infection possibly contributes $[74,75]$. Malabsorption is presumed to contribute to growth impairment but has not been causally linked to it. Multiple investigations 
suggest both direct and indirect mechanisms of disease, including luminal competition for nutrients, Giardiainduced epithelial cell damage (apoptosis [76,77], arrested proliferation [78], and tight-junction abnormalities $[76,77,79]) ; \mathrm{T}$ cell-mediated epithelial cell injury $[80,81]$, microvilli loss $[75,80-82]$, and disaccharidase deficiency $[83,84]$; nutrient-dependent growth impairment and decreased villus-to-crypt ratios [85]; and translocation of microbiota across the mucosa [86] (Figure 2).

\section{Unscrambling strain virulence and pathogenicity}

Of at least six recognized species of Giardia, only G. lamblia causes infections in humans. G. lamblia isolates are further divided into eight assemblages, designated A to $\mathrm{H}$. Among the assemblages, only assemblages A and B and their respective subtypes cause human infection. The relative proportion of assemblage A to assemblage $\mathrm{B}$ infection varies both temporally and spatially, with a predilection for more assemblage $\mathrm{B}$ infections in endemic settings [87-90].

Whole-genome sequencing has revealed that assemblage A and assemblage B laboratory isolates are quite dissimilar and may be better categorized as separate species [91]. Despite this genetic divergence, attempts to ascribe clinical variability and pathogenicity based on assemblage designation have been inconclusive. In separate studies, either assemblage A $[92,93]$ or assemblage B $[94,95]$ more strongly associates with diarrhea. A limitation in assessing assemblage-specific pathogenicity in naturally acquired infection is that targets used to differentiate between assemblages $\mathrm{A}$ and $\mathrm{B}-\beta$-giardin $(b g)$, glutamate dehydrogenase $(g d h)$, triose phosphate isomerase (tpi), and the small subunit 18S rRNA genesare not known virulence factors. Furthermore, studies that incorporate multilocus genotyping demonstrate a substantial proportion of specimens with mixed results $[96,97]$, raising the possibility of heterologous infections or even inter-assemblage recombination events $[98,99]$. Expanded comparative genomics studies investigating several assemblage A and assemblage B isolates may further clarify strain-specific pathogenicity.

In experimental conditions, Giardia strain is the strongest predictor of disease outcome. In initial volunteer studies, the axenized assemblage B isolate GS/M caused more symptoms than other isolates, a finding that was reproduced in murine models [30,100]. Laboratory assemblage A and assemblage $\mathrm{B}$ isolates have different growth characteristics in standard media conditions, and the former are more readily recoverable; however, assemblage $\mathrm{B}$ isolates are more infectious $[84,85]$. Historically, there has been significant experimental heterogeneity in laboratory studies [101], and this limits comparisons between investigators. When tested under identical conditions, however, there are apparent assemblage-dependent differences in induction or disruption of interleukin-8 (IL-8) from epithelial cells in vitro $[102,103]$ and ex vivo biopsies from patients with inflammatory bowel disease [104] and immunemediated disaccharidase deficiency in murine models [84]. Furthermore, in vitro models demonstrate that strain-dependent changes occur in epithelial cells [77] and that mixed assemblage co-cultivation, or cultivation with a clone expressing mixed assemblage traits, induces more epithelial cell apoptosis and tight-junction disruption than mono-infection with either assemblage A or B [105]. Finally, proximity to a natural source may also be relevant given that recently human-passaged strains were more infectious in an animal model than laboratory strains were [106] and that gerbil-passaged cysts achieve prolonged infections [85].

Advances in Giardia biology and gene regulation using transcriptomic and proteomic approaches aim to identify new virulence traits that could be confirmed in human infections. For example, as a possible means of evading host humoral and innate defenses, Giardia has a repertoire of 20 to $200 \mathrm{kDa}$ cysteine-rich proteins that densely coat the surface of trophozoites, termed variant surface proteins (VSPs). Although only a single VSP is expressed on an individual trophozoite, the breadth of potential VSPs (73 to 270 or more) $[91,107]$ in a given strain is associated with enhanced virulence [108]. How VSP switching occurs every 6-13 generations and what events trigger posttranscriptional VSP regulation $[107,109]$ and trafficking may help unravel parasite determinants of transient colonization opposed to chronic infection. The role of Giardia cathepsins as disease determinants also warrants further consideration $[102,103]$.

\section{Nutritional determinants of disease}

It is increasingly recognized that, within the luminal ecology of the human intestine, resident microbiota modify ingested nutrients and their metabolites, influencing nutrient availability and uptake. Giardia lacks fundamental enzymes necessary for generating critical biomolecules such as cholesterol and therefore must rely on acquisition of these materials from the luminal environment [110-112]. The parasite acquires nutrients primarily via bulk-phase uptake in endocytic vacuoles localized to the exposed dorsal (non-adherent) side [113], adheres to epithelial cells using the ventral disc [114,115], and may direct fluid flow toward adherent parasites via coordinated flagellar motion [116]. Arginine utilization represents an example of how shunting of key nutrients may provide an advantage to the parasite at a detriment to 
the host. Stadelmann and colleagues [117] demonstrated that Giardia isolates expressing arginine deiminase rapidly deplete arginine, resulting in epithelial cell cell-cycle arrest. Since both Giardia and epithelial cells use arginine for growth, an arginine-depleting mechanism could explain why, under conditions of arginine scarcity such as severe protein malnutrition, there is increased susceptibility to villus shortening during Giardia infection [85,118]. For the host, decreased availability of arginine also impairs inducible nitric oxide production by epithelial cells and may alter cellular immune responses $[119,120]$, whereas Giardia uses the sequestered arginine primarily for energy production via the arginine dehydrolase pathway. Host genetically determined pathways that facilitate arginine acquisition or utilization despite Giardia infection may be important for maintaining host resiliency during infection. For example, cellular arginine uptake occurs through the cationic transporter (CAT), and CAT expression is increased in some cell types in the presence of APO-E 4/4 allelotype [121]. The APO-E 4/4 allelotype confers protection against diarrhea in children [122,123] and Cryptosporidium infection in mice [121], and may also associate with better cognitive outcomes in Giardiainfected children [124].

There is mounting recognition of an intricate relationship between host nutrition and mucosal immune responses. Malnourished children, for example, have diminished seroconversion to some components of the oral polio vaccine [125]. In experimental models, malnutrition confers enhanced susceptibility to Cryptosporidium [126-128] and enteroaggregative Escherichia coli (EAEC) [129]. Zinc deficiency enhances susceptibility to Giardia [130] and diminishes inflammatory responses to EAEC [131]. In a chronic giardiasis model, protein malnutrition led to decreased expression of IL-4 and IL-5 and diminished B-cell populations in intestinal tissues, villus blunting, and growth failure despite a parasite burden similar to that of well-nourished infected controls [85]. These findings suggest that, in children with chronic giardiasis, nutritional status could similarly determine disease severity.

\section{Microbiota and co-pathogen interactions}

There is increasing recognition of the role of the nearly $10^{14}$ resident bacteria in regulating host metabolism during states of both obesity and undernutrition $[36,132]$ as well as immunity. In experimental giardiasis, the microbiota composition was shown to have more influence over susceptibility to infection than the absence of $\mathrm{CD}^{+} \mathrm{T}$ cells [133]. Thus, several experimental models rely on manipulating host microbiota through the use of antibiotic-containing water to promote infection $[84,85,103]$. Though sometimes necessary, the depletion of microbiota in these models may exclude important Giardia effects on microbiota that indirectly influence pathogenesis. Although attempts to identify small-bowel bacterial overgrowth in children with giardiasis have failed to show an association [134], microbiota from duodenal contents of Giardia-infected patients caused more inflammation than axenized Giardia trophozoites in germ-free mice [135]. Chen and colleagues [86] also observed that diverse populations of mucosally associated bacteria, including Lactobacillus, Streptococcus, and Staphylococcus species, are increased during experimental Giardia infection and after clearance of the parasite. Associated increases in the pro-inflammatory cytokines interferon-gamma (IFN- $\gamma$ ), tumor necrosis factor-alpha (TNF- $\alpha$ ), and myeloperoxidase were also seen [86]. The persistent translocation of mucosally associated bacterial microbiota has been proposed to explain post-infection irritable bowel syndrome and chronic fatigue [31], sequelae present in up to $5 \%$ of individuals with prior giardiasis [136], particularly in those whose initial course was more protracted [137]. Mechanisms by which Giardia could influence microbiota composition include alterations in the luminal nutritional environment as previously stated, as well as dampening the epithelial cell inflammatory responses through posttranslational reductions in IL-8 and decreased nitric oxide synthesis $[102,120,138-140]$.

Whether resident microbiota in the small intestine are protective against Giardia or promote chronic gastrointestinal disease may be conditional on their composition. When used as probiotics in experimental models, Lactobacillus species (L. johnsonii, L. casei, and L. rahmnosus GG) have been shown to promote Giardia clearance [141]. Concurrently, these Lactobacillus species enhance proinflammatory responses and improve histopathological parameters [142-144]. Furthermore, bacteriocins produced by L. acidophilus (P106) and L. plantarum (P164) reduced parasite adhesion $[145,146]$. The fermented milk product kefir, which contains a combination of lactic acid bacteria (lactobacillus, lactococci, and Leuconostoc), acetic acid bacteria, and yeast, protected mice against G. lamblia trophozoite infection and enhanced pro-inflammatory responses, including IFN- $\gamma$ and TNF- $\alpha$, with a decrease in $\mathrm{CD} 4^{+} \mathrm{T}$-cell expansion [147]. Interestingly, activation of Toll-like receptor 2 (TLR2) signaling in murine dendritic cells, as occurs in response to some Lactobacillus species, in combination with TLR1 or TLR6, leads to increased IL-12/ 23p40, IL-23, and IL-10 secretion in the presence of Giardia lysate [148], whereas Giardia lysates decrease IL-12p70 and IL-23 but increase IL-10 responses to TLR4 agonists [148]. The down-regulatory effect of Giardia lysate on dendritic cell responses to TLR4 agonists has been shown to be dependent on phosphoinositide 3-kinase 
inhibition and may depend on Giardia arginine deiminase $[78,149]$. In contrast, Giardia lysates have no regulatory effect on bovine monocyte-derived dendritic cells [150].

The influence of Giardia-mediated changes in the luminal ecology may also alter susceptibility to other co-infecting enteropathogens, which are now recognized to be more common than mono-infections in children in resource-limited settings [34]. Furthermore, only a narrow margin separates the mean number of coenteropathogens found in non-diarrheal specimens $(4.3 \pm 0.1)$ from the number in diarrheal specimens (5.6 \pm 0.1$)$ [34]. In some populations, up to $75 \%$ of Giardia infections include co-enteropathogens, most commonly with Vibrio cholerae and rotavirus [151] and elsewhere with norovirus and enteropathogenic E. coli [46]. Cases of co-infections with Tropheryma whipplei have also been reported [152]. In rural Ecuador, the OR for diarrhea with rotavirus infection was $6-14.8$, but G. lamblia with rotavirus increased the OR to 11-24.13. However, Giardia co-infection with enterotoxigenic Escherichia coli, Campylobacter, Cryptosporidium, and enteroinvasive Escherichia coli did not demonstrate an increased risk of diarrhea, suggesting specificity to Giardia co-pathogen interactions [153]. On the other hand, associations between decreased risk of acute diarrhea in Giardia-infected cohorts raise questions that require additional investigation of whether Giardia decreases susceptibility to some pathogens or attenuates their severity. Cotton and colleagues [103], for example, demonstrated that Giardia infection diminished neutrophil chemotaxis and inflammation in a model of Clostridium difficile toxin-induced colitis.

\section{Host responses and disease pathogenesis}

The duality of host immune response in Giardia pathogenesis is complex and has been reviewed extensively [83,154]. Increasingly, redundant mechanisms of immunologic control are being identified, including chemokines (CCL2, CCL20, CXCL1, CXCL2, and CXCL3) from epithelial cells [155], IL-6 derived from dendritic cells and possibly mast cells [156-158], TNF- $\alpha$ [159], $\alpha$-defensins activated by matrix metalloprotease 7 (Mmp7) [159], and nitric oxide generated from either nitric oxide synthase 1 (NOS1) or NOS2 [159-161]. Data from isolated outbreaks and experimental models demonstrate a mixed immune response consisting of both antibody production $[162,163]$ and mucosal and systemic Th1-type CD4 ${ }^{+}$T-cell responses $[84,164,165]$. Studies in populations with serial outbreaks demonstrate that exposure to Giardia can promote protective immunity [166], which is characterized by a predominance of circulating $\mathrm{T}$ cells with a Th1-memory phenotype $\left(\mathrm{CD} 25^{+} \mathrm{CD} 26^{\text {bright }}\right.$ cells that produce IFN- $\left.\gamma\right)$ [165]. Also, the absence of $\mathrm{CD} 4^{+} \mathrm{T}$ cells leads to more prolonged infection in experimental models [84].

Despite evidence for the role of $\mathrm{T}$ cells in protective immunity, clinical observations suggest that humoral responses are critical for immunity. These studies demonstrate greater prevalence of Giardia cysts and more symptomatology in patients with hypogammaglobulinemia (that is, $\mathrm{x}$-linked agammaglobulinemia [Bruton's disease] and common variable immunodeficiency) [167-169] than those with T-cell deficits (advanced AIDS or thymic aplasia). Decreased secretory IgA variably associates with increased risk [170] and impaired IgA responses are seen in children with persistent Giardia infection [171]. In animal models, the majority of genes expressed in experimental murine infections are related to antibody production [159], and IgA-deficient knockout mice have difficulty clearing Giardia [172]. The polymeric Ig receptor, which transports IgA and IgM across the epithelium, is essential for eliminating G. muris from murine hosts, further supporting possible dependence on mucosal secretory antibody responses for eradication of infection [173].

In addition to facilitating parasite clearance, the secondary host immune response to Giardia may promote pathologic changes [84,174]. CD8 $^{+} \mathrm{T}$ cells may contribute to villus [85] and microvillus [175] shortening in G. lamblia infection as demonstrated in models of murine giardiasis (G. muris) $[80,81,84]$. In addition, brush border actin cytoskeletal changes in ezrin and villin and disaccharidase deficiency after G. lamblia infection are dependent on T-cell responses [174]. Clinical findings also demonstrate that subsets of infected symptomatic adults [74] and some children show increased lymphocytic infiltrates as well as decreased villus-to-crypt ratios [72] on histological biopsy. Decreased villus surface area in patients with chronic giardiasis coincides with increased T-cell populations and epithelial cell apoptosis [74], and may similarly suggest immune-mediated diffuse microvillus shortening seen in some patients with giardiasis [82]. A murine model using freshly acquired gerbil-passaged G. lamblia cysts in combination with antibiotic-containing water to reduce resident microbiota similarly demonstrated persistent parasitism, with increased mucosal T cells and epithelial cell apoptosis through 9 weeks in immunocompetent hosts, suggesting that some Giardia strains that evade host responses can promote chronic mucosal inflammation [85].

Such chronic and repeated Giardia exposures are common in children in low-income settings who also have a high prevalence of malnutrition and an increasingly recognized gut dysfunction with chronic intestinal inflammation, increased gut permeability, and reduced 
villus length, termed environmental enteropathy [11]. Few studies have characterized immune responses to Giardia in these children. Kohli and colleagues [87] identified inflammatory diarrhea by using fecal lactoferrin during the first case (but not subsequent cases) of Giardia, and Long and colleagues [176] demonstrated increased IL-4, IL-5, monocyte chemoattractant protein-1 (MCP-1), and IFN- $\gamma$ but decreased IL-8 in children with more prolonged episodes of Giardia. Thus, relationships between intestinal inflammatory response and Giardia infection may influence disease outcomes in these children.

Elucidation of immune-protective responses in contrast to those that might directly promote enteropathy in these children could also help guide vaccine development. Currently, the only licensed vaccine, GiardiaVax, is for use only in canines and has modest efficacy [177]. Attempts to identify correlates of protection in children in low-resource endemic settings are inconclusive. For example, data from Bangladesh demonstrated that, although human breast milk has direct anti-Giardia properties and may contain high concentrations of antiGiardia antibodies [18], there is no correlation between the presence of Giardia-specific antibodies in breast milk and incidence, severity, or recurrence of Giardia in these children [178]. Potential approaches to vaccine development include targeting the repertoire of G. lamblia VSPs, since purified VSPs can protect against primary infection in experimental models [179]. Another vaccine candidate, $\alpha 1$-giardin expressed in an attenuated Salmonella vector, showed efficacy in mice, but $\alpha$-enolase and ornithine carbamoyl transferase did not [180]. Challenging field vaccine application is the recognition that some mucosal vaccines are less effective in children in low-resource settings, with an as-of-yet unidentified but hypothesized immunologic hurdle in the setting of malnutrition [125], adding another layer of complexity to this preventive strategy.

\section{Conclusions}

G. lamblia remains an enigmatic parasite with potential influence over health and development in children in endemic resource-limited settings where infection is nearly universal. One conclusion explaining the variable outcomes in both field studies and experimental models is that Giardia may not conform to traditional concepts of the 'commensal' or 'pathogenic' microbe and at times may promote states of either mucosal protection or disease. Therefore, discerning the direct effects of various Giardia strains from indirect effects mediated through the parasite's influence on a complex and dynamic luminal ecology and host mucosal homeostasis will be a critical step toward translating basic laboratory findings to outcomes in human disease. Such understanding could lead to improved interventions for chronic giardiasis, as well as environmental enteropathy and childhood malnutrition, while also identifying properties of the organism that could be exploited for the promotion of human health.

\section{Abbreviations}

APO-E, apolipoprotein E; CAT, cationic transporter; CI, confidence interval; EAEC, enteroaggregative Escherichia coli; IFN- $\gamma$, interferon-gamma; IL, interleukin; NOS, nitric oxide synthase; OR, odds ratio; TLR, Toll-like receptor; TNF- $\alpha$, tumor necrosis factor-alpha; VSP, variant surface protein; WHO, World Health Organization.

\section{Disclosures}

The authors declare that they have no disclosures.

\section{Acknowledgments}

We thank Richard L. Guerrant, Cirle A. Warren, Leana Guerin, Scott Dawson, and Jörg-Dieter Schulzke for their insights and assistance with figure preparation. Support was received from National Institutes of Health/National Institute of Allergy and Infectious Diseases grant K08AI108730-01 to Luther A. Bartelt.

\section{References}

I. Ryan ET, Wilson ME, Kain KC: Illness after international travel. $N$ Engl J Med 2002, 347:505-16.

2. Fraser D, Dagan R, Naggan L, Greene V, El-On J, Abu-Rbiah Y, Decklebaum R: Natural history of Giardia lamblia and Cryptosporidium infections in a cohort of Israeli Bedouin infants: a study of a population in transition. Am J of Trop Med and Hyg 1997, 57:5449.

3. Muhsen $\mathrm{K}$, Levine MM: A systematic review and meta-analysis of the association between Giardia lamblia and endemic pediatric diarrhea in developing countries. Clin Infect Dis 2012, 55 (Suppl 4):S27I-93.

FlOOOPrime
RECOMMENDED

4. Ross AG, Olds GR, Cripps AW, Farrar JJ, McManus DP: Enteropathogens and chronic illness in returning travelers. $N \mathrm{EnglJ}$ Med 2013, 368:1817-25.

5. Ankarklev J, Jerlström-Hultqvist J, Ringqvist E, Troell K, Svärd SG: Behind the smile: cell biology and disease mechanisms of Giardia species. Nat Rev Microbiol 2010, 8:4I3-22.

FlOOOPrime RECOMMENDED

6. Hill DR, Nash TE: Intestinal flagellate and ciliate infections. Tropical infectious diseases: Principles, Pathogens, \& Practice. $3^{\text {rd }}$ edition. Edited by Guerrant RL, Walker DH, Weller PF. Philadelphia: Churchill Livingtson; 201 1:623-32.

7. Haque R, Mondal D, Karim A, Molla IH, Rahim A, Faruque ASG, Ahmad N, Kirkpatrick BD, Houpt E, Snider C, Petri WA: Prospective case-control study of the association between common enteric protozoal parasites and diarrhea in Bangladesh. Clin Infect Dis 2009, 48:1191-7.

8. Solaymani-Mohammadi S, Genkinger JM, Loffredo CA, Singer SM: A meta-analysis of the effectiveness of albendazole compared with metronidazole as treatments for infections with Giardia duodenalis. PLoS Negl Trop Dis 2010, 4:e682. 
9. Rossignol JF: Cryptosporidium and Giardia: treatment options and prospects for new drugs. Exp Parasitol 2010, 124:45-53.

10. Savioli L, Smith H, Thompson A: Giardia and Cryptosporidium join the 'Neglected Diseases Initiative'. Trends Parasitol 2006, 22:203-8.

II. Bartelt LA, Lima AA, Kosek M, Peñataro Yori P, Lee G, Guerrant RL: 'Barriers' to child development and human potential: the case for including the 'neglected enteric protozoa' (NEP) and other enteropathy-associated pathogens in the NTDs. PLoS Negl Trop Dis 2013, 7:e2125.

12. Thompson RC, Monis P: Giardia-from genome to proteome. Adv Parasitol 2012, 78:57-95.

13. Baruch AC, Isaac-Renton J, Adam RD: The molecular epidemiology of Giardia lamblia: a sequence-based approach. J of Infect Dis 1996, I74:233-6.

14. Hogan JN, Daniels ME, Watson FG, Conrad PA, Oates SC, Miller MA, Hardin D, Byrne BA, Cominik C, Melli A, Jessup DA, Miller WA: Longitudinal Poisson regression to evaluate the epidemiology of Cryptosporidium, Giardia, and fecal indicator bacteria in coastal California wetlands. Appl Environ Microbiol 2012, 78:3606-13

15. Gomez-Puerta LA, Lopez-Urbina MT, Alarcon V, Cama V, Gonzalez AE, Xiao L: Occurrence of Giardia duodenalis assemblages in alpacas in the Andean region. Parasitol Int 2014, 63:31-4.

16. García-Presedo I, Pedraza-Díaz S, González-Warleta M, Mezo M, Gómez-Bautista M, Ortega-Mora LM, Castro-Hermida JA: The first report of Cryptosporidium bovis, C. ryanae and Giardia duodenalis sub-assemblage A-II in roe deer (Capreolus capreolus) in Spain. Vet Parasitol 2013, 197:658-64.

17. Feng $Y$, Xiao L: Zoonotic potential and molecular epidemiology of Giardia species and giardiasis. Clin Microbiol Rev 201I, 24: I 10-40.

18. Hill DR, Nash TE: Giardiais. In: Mandell, Douglas, and Bennet's Principles and Practice of Infectious Disease. 8th edition. Edited by Bennett JE, Dolin R, Blaser MJ. Saunders: Elsevier; 2015:28I, 3154-60.e3.

19. Traub RJ, Monis PT, Robertson I, Irwin P, Mencke N, Thompson RC: Epidemiological and molecular evidence supports the zoonotic transmission of Giardia among humans and dogs living in the same community. Parasitiology 2004, I 28:253-62.

20. Lipoldová M: Giardia and Vilém Dušan Lambl. PLoS Negl Trop Dis 2014, 8:e2686.

21. Mahmoudi MR, Kazemi B, Mohammadiha A, Mirzaei A, Karanis P: Detection of Cryptosporidium and Giardia (oo)cysts by IFA, PCR, and LAMP in surface water from Rasht, Iran. Trans $R$ Soc Trop Med Hyg 2013, 107:5II-7.

22. Mohamed AS, Levine M, Camp JW, Lund E, Yoder JS, Glickman LT, Moore GE: Temporal patterns of human and canine Giardia infection in the United States: 2003-2009. Prev Vet Med 2014, I I 3:249-56.

23. Kitajima M, Haramoto $E$, Iker BC, Gerba CP: Occurrence of Cryptosporidium, Giardia, and Cyclospora in influent and effluent water at wastewater treatment plants in Arizona. Sci Total Environ 2014, 484:129-36.

24. Sroka J, Stojecki K, Zdybel J, Karamon J, Cencek T, Dutkiewicz J: Occurrence of Cryptosporidium oocysts and Giardia cysts in effluent from sewage treatment plant from eastern Poland. Ann Agric Environ Med 2013, 1:57-62.

25. ElBakri A, Samie A, Bessong P, Potgieter N, Odeh RA: Detection and molecular characterization of Giardia lamblia genotypes in Sharjah, United Arab Emirates. Trans R Soc Trop Med Hyg 2014, 108:466-73.

26. Enserink $R$, van den Wijngaard $C$, Bruijning-Verhagen $P$, van Asten $L$, Mughini-Gras L, Duizer E, Kortbeek T, Scholts R, Nagelkerke N, Smit HA, Kooistra-Smid M, van Pelt W: Gastroenteritis attributable to 16 Enteropathogens in children attending day care. Significant effects of rotavirus, norovirus, astrovirus, Cryptosporidium and Giardia. Pediatr Infect Dis J 2014, [Epub ahead of print].
27. Adell AD, Smith WA, Shapiro K, Melli A, Conrad PA: Molecular Epidemiology of Cryptosporidium spp. and Giardia spp. in Mussels (Mytilus californianus) and California Sea Lions (Zalophus californianus) from Central California. Appl Environ Microbiol 2014, 80:7732-40.

28. Giangaspero A, Papini R, Marangi M, Koehler AV, Gasser RB: Cryptosporidium parvum genotype Ila and Giardia duodenalis assemblage A in Mytilus galloprovincialis on sale at local food markets. Int J Food Microbiol 2014, I7 I:62-7.

29. Schets FM, van den Berg HH, de Roda Husman AM: Determination of the recovery efficiency of Cryptosporidium oocysts and Giardia cysts from seeded bivalve mollusks. J Food Prot 2013, 76:93-8.

30. Nash TE, Herrington DA, Losonsky GA, Levine MM: Experimental human infections with Giardia lamblia. I Infect Dis 1987, 156:974-84.

\section{FlOOOPrime}

3I. Hanevik K, Wensaas KA, Rortveit G, Eide GE, Mørch K, Langeland N: Irritable bowel syndrome and chronic fatigue 6 years after Giardia infection: a controlled prospective cohort study. Clin Infect Dis 2014, 59:1394-400.

\section{FlOOOPrime}

RECOMMENDED

32. Al-Mekhlafi MS, Azlin M, Nor Aini U, Shaik A, Sa'iah A, Fatmah MS, Ismail MG, Ahmad Firdaus MS, Asiah MY, Rozlida AR, Morhayati M: Giardiasis as a predictor of childhood malnutrition in Orang Asli children in Malaysia. Trans R Soc Trop Med Hyg 2005, 99:686-91.

\section{FlOOOPrime}

33. Berkman DS, Lescano AG, Gilman RH, Lopez SL, Black MM: Effects of stunting, diarrhoeal disease, and parasitic infection during infancy on cognition in late childhood: a follow-up study. Lancet 2002, 359:564-71.

\section{FlOOOPrime
RECOMMENDED}

34. Taniuchi M, Sobuz SU, Begum S, Platts-Mills JA, Liu J, Yang Z, Wang Xin-Qun, Petri WA, Haque R, Houpt ER: Etiology of diarrhea in Bangladeshi infants in the first year of life analyzed using molecular methods. J Infect Dis 2013, 208: $1794-802$.

35. Korpe PS, Petri WA: Environmental enteropathy: critical implications of a poorly understood condition. Trends Mol Med 20I2, 18:328-36.

36. Smith MI, Yatsunenko T, Manary MJ, Trehan I, Mkakosya R, Chang J, Kau AL, Rich SS, Concannon P, Mychaleckyj JC, Liu J, Houpt E, Li JV, Holmes E, Nicholson J, Knights D, Ursell LK, Knight R, Gordon Jl: Gut microbiomes of Malawian twin pairs discordant for kwashiorkor Science 2013, 339:548-54.

\section{FlOOOPrime} RECOMMENDED

37. Boadi S, Polley SD, Kilburn S, Mills GA, Chiodini PL: A critical assessment of two real-time PCR assays targeting the (SSU) rRNA and gdh genes for the molecular identification of Giardia intestinalis in a clinical laboratory. J Clin Pathol 2014, 67:811-6

38. Heyworth MF: Diagnostic testing for Giardia infections. Trans $R$ Soc Trop Med Hyg 2014, 108:123-5.

39. Liu J, Kabir F, Manneh J, Lertsethtakarn P, Begum S, Gratz J, Becker SM, Operario DJ, Taniuchi M, Janaki L, Platts-Mills JA, Haverstick DM, Kabir M, Sobuz SU, Nakjarung K, Sakpaisal P, Silapong S, Bodhidatta L, Qureshi S, Kalam A, Saidi Q, Swai N, Mujaga B, Maro A, Kwambana B, Dione M, Antonio M, Kibiki G, Mason CJ, Haque R, et al: Development and assessment of molecular diagnostic tests for 15 enteropathogens causing childhood diarrhoea: a multicentre study. Lancet Infect Dis 2014 , 14:716-24. 
40. Mejia R, Vicuña Y, Broncano N, Sandoval C, Vaca M, Chico M, Cooper PJ, Nutman TB: A novel, multi-parallel, real-time polymerase chain reaction approach for eight gastrointestinal parasites provides improved diagnostic capabilities to resource-limited at-risk populations. Am J Trop Med Hyg 2013, 88:104|-7.

4I. Kotloff KL, Nataro JP, Blackwelder WC, Blackwelder WC, Nasrin D, Farag TH, Panchalingam S, Wu Y, Sow S, Sur D, Breiman RF, Faruque AS, Zaidi AK, Saha D, Alonso PL, Tamboura B, Sanogo D, Onwuchekwa U, Manna B, Ramamurthy T, Kanungo S, Ochieng JB, Omore R, Oundo JO, Hossain A, Das SK, Ahmed S, Qureshi S, Quadri F, Adegbola RA, et al: Burden and aetiology of diarrhoeal disease in infants and young children in developing countries (the Global Enteric Multicenter Study, GEMS): a prospective, case-control study. Lancet 2013, 382:209-22.

\section{FlOOOPrime} RECOMMENDED

42. Veenemans I, Schouten LR, Ottenhof MJ, Mank TG, Uges DRA, Mbugi EV, Demir AY, Kraaijenhagen RJ, Savelkoul HFJ, Verhoef H: Effect of preventive supplementation with zinc and other micronutrients on non-malarial morbidity in Tanzanian preschool children: a randomized trial. PLoS One 20I2, 7:e4I630.

\section{FlOOOPrime}

43. Muhsen K, Cohen D, Levine MM: Can Giardia lamblia infection lower the risk of acute diarrhea among preschool children? J Trop Pediatr 2014, 60:99-103.

44. Mata LJ, Urrutia JJ, Lechtig A: Infection and nutrition of children of a low socioeconomic rural community. Am J Clin Nutr I97I, 24:249-59.

45. Farthing MJ, Mata L, Urrutia J], Kronmal RA: Natural history of Giardia infection of infants and children in rural Guatemala and its impact on physical growth. Am J Clin Nutr 1986, 43:395-405.

46. Becker-Dreps S, Bucardo F, Vilchez S, Zambrana LE, Liu L, Weber DJ, Rodolfo P, Barclay L, Vinjé J, Hudgens MG, Nordgren J, Svensson L, Morgan DR, Espinoza F, Paniagua M: Etiology of childhood diarrhea after rotavirus vaccine introduction: A prospective, population-based study in Nicaragua. Pediatr Infect Dis J 2014, 33:1156-63

47. Prado MS, Cairncross S, Strina A, Barreto ML, Oliveira-Assis AM, Rego S: Asymptomatic giardiasis and growth in young children; a longitudinal study in Salvador, Brazil. Parasitology 2005, | |31:51-6.

48. Boeke CE, Mora-Plazas M, Forero Y, Villamor E: Intestinal protozoan infections in relation to nutritional status and gastrointestinal morbidity in Colombian school children. j Trop Pediatr 2010, 56:299-306.

49. Sackey ME, Weigel MM, Armijos RX: Predictors and nutritional consequences of intestinal parasitic infections in rural Ecuadorian children. J Trop Pediatr 2003, 49:17-23.

50. Goto R, Panter-Brick C, Northrop-Clewes CA, Manahdhar R, Tuladhar NR: Poor intestinal permeability in mildly stunted Nepali children: associations with weaning practices and Giardia lamblia infection. $\mathrm{Br}$ 」 Nutr 2002, 88: 141-9.

5I. Ignatius R, Gahutu JB, Klotz C, Steininger C, Shyirambere C, Lyng M, Musemakweri A, Aebischer T, Martus P, Gundel H, Mockenhaupt FP: High prevalence of Giardia duodenalis Assemblage B infection and association with underweight in Rwandan children. PLoS Negl Trop Dis 2012, 6:el677.

52. Ajjampur SSR, Koshy B, Venkataramani M, Sarkar R, Joseph AA, Jacob KS, Ward H, Kang G: Effect of cryptosporidial and giardial diarrhoea on social maturity, intelligence and physical growth in children in a semi-urban slum in south India. Ann Trop Paediatr 201 I, 31:205-12.

53. Newman RD, Moore SR, Lima AA, Nataro JP, Guerrant RL, Sears CL: A longitudinal study of Giardia lamblia infection in north-east Brazilian children. Trop Med Int Health 200I, 6:624-34.

54. Botero-Garcés JH, García-Montoya GM, Grisales-Patiño D, AguirreAcevedo DC, Alvarez-Uribe MC: Giardia intestinalis and nutritional status in children participating in the complementary nutrition program, Antioquia, Colombia, May to October 2006. Rev Inst Med Trop Sao Paulo 2009, 51:155-62.

55. Ish-Horowicz M, Korman SH, Shapiro M, Har-Even U, Tamir I, Strauss N, Deckelbaum RJ: Asymptomatic giardiasis in children. Pediatr Infect Dis J 1989, 8:773-9.

56. Moya-Camarena SY, Sotelo N, Valencia ME: Effects of asymptomatic Giardia intestinalis infection on carbohydrate absorption in well-nourished Mexican children. Am J Trop Med Hyg 2002, 66:255-9.

57. Hollm-Delgado M-G, Gilman RH, Bern C, Cabrera L, Sterling CR, Black RE, Checkley W: Lack of an adverse effect of Giardia intestinalis infection on the health of Peruvian children. $\mathrm{Am} J$ Epidemiol 2008, 168:647-55.

58. MAL-ED Network Investigators: The MAL-ED study: a multinational and multidisciplinary approach to understand the relationship between enteric pathogens, malnutrition, gut physiology, physical growth, cognitive development, and immune responses in infants and children up to 2 years of age in resource-poor environments. Clin Infect Dis 2014, 59 (Suppl 4):SI93-206.

59. Ochoa TJ, Chea-Woo E, Campos M, Pecho I, Prada A, McMahon RJ, Cleary TG: Impact of lactoferrin supplementation on growth and prevalence of Giardia colonization in children. Clin Infect Dis 2008, 46: $188 \mid-3$.

60. Muniz-Junqueira MI, Queiroz EF: Relationship between proteinenergy malnutrition, vitamin $A$, and parasitoses in living in Brasília. Rev Soc Bras Med Trop 2002, 35: |33-4|

61. Quihui-Cota L, Astiazarán-García H, Valencia ME, MoralesFigueroa GG, Lopez-Mata MA, Vazquez Ortiz F: Impact of Giardia intestinalis on vitamin a status in schoolchildren from northwest Mexico. Int J Vitam Nutr Res 2008, 78:5I-6.

62. Ertan P, Yereli K, Kurt O, Balcioğlu IC, Onağ A: Serological levels of zinc, copper and iron elements among Giardia lamblia infected children in Turkey. Pediatr Int 2002, 44:2868.

63. Abou-Shady O, El Raziky MS, Zaki MM, Mohamed RK: Impact of Giardia lamblia on growth, serum levels of zinc, copper, and iron in Egyptian children. Biol Trace Elem Res 201I, 140:1-6.

64. Rosado JL, Caamaño MC, Montoya YA, de Lourdes Solano M, Santos JI, Long KZ: Interaction of zinc or vitamin A supplementation and specific parasite infections on Mexican infants' growth: a randomized clinical trial. Eur J Clin Nutr 2009, 63:1176-84.

65. Astiazaran-Garcia H, Lopez-Teros $\mathrm{V}$, Valencia ME, Vazquez-Ortiz F, Sotelo-Cruz N, Quihui-Cota L: Giardia lamblia infection and its implications for vitamin $\mathbf{A}$ liver stores in school children. Ann Nutr Metab 2010, 57:228-33.

66. Martinez-Gordillo M, Gonzalez-Maciel A, Reynoso-Robles R, MontijoBarrios E, Ponce-Macotela M: Intraepithelial Giardia intestinalis: a case report and literature review. Medicine 2014, 93:e277.

67. Hjelt K, Paerregaard A, Krasilnikoff PA: Giardiasis causing chronic diarrhoea in suburban Copenhagen: incidence, physical growth, clinical symptoms and small intestinal abnormality. Acta Paediatr 1992, 81:881-6.

68. Behera B, Mirdha BR, Makharia GK, Bhatnagar S, Dattagupta S, Samantaray JC: Parasites in patients with malabsorption syndrome: a clinical study in children and adults. Dig Dis Sci 2008, 53:672-9.

69. Solomons NW. Giardiasis: nutritional implications. Rev Infect Dis 1982, 4:859-69.

70. Rana SV, Bhasin DK, Vinayak VK: Lactose hydrogen breath test in Giardia lamblia-positive patients. Dig Dis Sci 2005, 50:259-61.

7I. Oberhuber G, Kastner N, Stolte M: Giardiasis: a histologic analysis of 567 cases. Scand J Gastroenterol 1997, 32:48-5I.

72. Koot BG, ten Kate FJ, Juffrie M, Rosalina I, Taminiau JJ, Benninga MA: Does Giardia lamblia cause villous atrophy in children?: A retrospective cohort study of the histological abnormalities in giardiasis. J Pediatr Gastroenterol Nutr 2009, 49:304-8. 
73. Hanevik K, Hausken T, Morken MH, Strand EA, Mørch K, Coll P, Helgeland $L$, Langeland $N$ : Persisting symptoms and duodenal inflammation related to Giardia duodenalis infection. J Infect 2007, 55:524-30.

74. Troeger $H$, Epple $H$, Schneider $T$, Wahnschaffe $U$, Reiner $U$, Burchard G-D, Jelinek T, Zeitz M, Fromm M, Schulzke J-D: Effect of chronic Giardia lamblia infection on epithelial transport and barrier function in human duodenum. Gut 2007, 56:328-35.

\section{FloOOPrime}

\section{RECOMMENDED}

75. Buret A, Hardin JA, Olson ME, Gall DG: Pathophysiology of small intestinal malabsorption in gerbils infected with Giardia lamblia. Gastroenterology 1992, 103:506-13.

76. Panaro MA, Cianciulli A, Mitolo V, Mitolo $\mathrm{Cl}$, Acquafredda $\mathrm{A}$, Brandonisio O, Cavallo P: Caspase-dependent apoptosis of the HCT-8 epithelial cell line induced by the parasite Giardia intestinalis. FEMS Immunol Med Microbiol 2007, 5 I:302-9.

77. Chin AC, Teoh DA, Scott KG, Meddings JB, Macnaughton WK, Buret AG: Strain-dependent induction of enterocyte apoptosis by Giardia lamblia disrupts epithelial barrier function in a caspase-3-dependent manner. Infect Immun 2002, 7:3673-80.

78. Banik S, Renner Viveros P, Seeber F, Klotz C, Ignatius R, Aebischer T: Giardia duodenalis arginine deiminase modulates the phenotype and cytokine secretion of human dendritic cells by depletion of arginine and formation of ammonia. Infect Immun 2013, 8I:2309-I7.

79. Teoh DA, Kamieniecki D, Pang G, Buret AG: Giardia lamblia rearranges $\mathrm{F}$-actin and alpha-actinin in human colonic and duodenal monolayers and reduces transepithelial electrical resistance. J Parasitol 2000, 86:800-6.

80. Scott KG, Logan MR, Klammer GM, Teoh DA, Buret AG: Jejunal brush border microvillous alterations in Giardia murisinfected mice: role of T lymphocytes and interleukin-6. Infect Immun 2000, 68:34I2-8.

8I. Scott KG, Yu LC, Buret AG: Role of CD8+ and CD4+ T lymphocytes in jejunal mucosal injury during murine giardiasis. Infect Immun 2004, 72:3536-42.

82. Barbieri $D$, de Brito $T$, Hoshino $S$, Nascimento $F a O B$, Martins Campos J, Quarentei G, Marcondes E: Giardiasis in Childhood: Absorption Tests and Biochemistry, Histochemistry, Light, and Electron Microscopy of Jejunal Mucosa. Arch Dis Child 1970, 45:466-72.

83. Solaymani-Mohammadi S, Singer SM: Giardia duodenalis: the double-edged sword of immune responses in giardiasis. Exp Parasitol 2010, 126:292-7.

\section{FlOOOPrime}

\section{RECOMMENDED}

84. Solaymani-Mohammadi S, Singer SM: Host immunity and pathogen strain contribute to intestinal disaccharidase impairment following gut infection. J of Immunol 201 I, 187:3769-75.

\section{FlOOOPrime}

\section{RECOMMENDED}

85. Bartelt LA, Roche J, Kolling G, Bolick D, Noronha F, Naylor C, Hoffman P, Warren C, Singer S, Guerrant R: Persistent, G. lamblia impairs growth in a murine malnutrition model. J Clin Invest 2013, I 23:2672-84

86. Chen TL, Chen S, Wu HW, Lee TC, Lu YZ, Wu LL, Ni YH, Sun CH, Yu WH, Buret AG, Yu LCH: Persistent gut barrier damage and commensal bacterial influx following eradication of Giardia infection in mice. Gut Pathog 2013, 5:26.

\section{FlOOOPrime RECOMMENDED}

87. Kohli A, Bushen OY, Pinkerton RC, Houpt E, Newman RD, Sears CL, Lima AAM, Guerrant RL: Giardia duodenalis assemblage, clinical presentation and markers of intestinal inflammation in Brazilian children. Trans R Soc Trop Med Hyg 2008, 102:718-25.

88. Asher AJ, Holt DC, Andrews RM, Power ML: Distribution of Giardia duodenalis Assemblages, A and B among Children
Living in a Remote Indigenous Community of the Northern Territory, Australia. PLoS One 20I4, 9:el I 2058.

89. Helmy YA, Klotz C, Wilking H, Jürgen K, Nöckler K, Von SamsonHimmelstjerna G, Zessin KH, Aebischer T: Epidemiology of Giardia duodenalis infection in ruminant livestock and children in the Ismailia province of Egypt: insights by genetic characterization. Parasit Vectors 2014, 7:321.

90. Choy SH, Al-Mekhlafi HM, Mahdy MA, Nasr NN, Sulaiman M, Lim YAL, Surin J: Prevalence and associated risk factors of Giardia infection among indigenous communities in rural Malaysia. Sci Rep 2014, 4:6909.

91. Adam RD, Dahlstrom EW, Martens CA, Bruno DP, Barbia KD, Ricklefs SM, Hernandez MM, Narla NP, Patel RB, Porcella SF, Nash TE: Genome sequencing of Giardia lamblia genotypes A2 and B isolates and comparative analysis with the genomes of genotypes AI and E (WB and Pig). Genome Biol Evol 2013, 5:2498-5II.

\section{FIOOOPrime \\ RECOMMENDED}

92. Haque R, Roy S, Kabir M, Stroup SE, Mondal D, Houpt ER: Giardia assemblage $\mathbf{A}$ infection and diarrhea in Bangladesh. J Infect Dis 2005, 192:217|-3.

93. Pestechian N, Rasekh H, Rostami-Nejad M, Yousofi HA, HosseiniSafa A: Molecular identification of Giardia lamblia; is there any correlation between diarrhea and genotyping in Iranian population? Gastroenterol Hepatol Bed Bench 2014, 7:168-72.

94. ElBakri A, Samie A, Bessong P, Potgieter N, Odeh RA: Detection and molecular characterization of Giardia lamblia genotypes in Sharjah, United Arab Emirates. Trans R Soc Trop Med Hyg 2014, 108:466-73.

95. Puebla LJ, Núñez FA, Fernández YA, Fraga J, Rivero LR, Millán IA, Valdés, Silva Im: Correlation of Giardia duodenalis assemblages with clinical and epidemiological data in Cuban children. Infect Genet Evol 2014, 23:7-12.

96. Laishram S, Kannan A, Rajendran P, Kang G, Ajjampur SS: Mixed Giardia duodenalis assemblage infections in children and adults in South India. Epidemiol Infect 2012, 140:2023-7.

97. Broglia A, Weitzel T, Harms G, Cacció SM, Nöckler K: Molecular typing of Giardia duodenalis isolates from German travellers. Parasitol Res 2013, I I 2:3449-56.

98. Liu A, Yang F, Shen Y, Zhang W, Wang R, Zhao W, Zhang L, Ling H, Cao J: Genetic analysis of the Gdh and Bg genes of animalderived Giardia duodenalis isolates in Northeastern China and evaluation of zoonotic transmission potential. PLoS One 2014, 9:e95291.

99. Wang H, Zhao G, Chen G, Jian F, Zhang S, Feng C, Wang R, Zhu J, Dong $\mathrm{H}$, Hua J, Wang $M$, Zhang L: Multilocus genotyping of Giardia duodenalis in dairy cattle in Henan, China. PLOS One. 20।4, 9:el00453.

100. Byrd LG, Conrad JT, Nash TE: Giardia lamblia infections in adult mice. Infect Immun 1994, 62:3583-5.

10I. Adell AD, Miller WA, Harvey DJ, Van Wormer E, Wuertz S, Conrad PA: Individual subject meta-analysis of parameters for Giardia duodenalis shedding in animal experimental models. Biomed Res Int 2014, 2014:476|42.

102. Lee HY, Hyung S, Lee NY, Yong TS, Han SH, Park SJ: Excretorysecretory products of Giardia lamblia induce interleukin-8 production in human colonic cells via activation of $\mathrm{p} 38$, ERK I/2, NF-KB and AP-I. Parasite Immunol 20I2, 34:I83-98.

103. Cotton JA, Bhargava A, Ferraz JG, Yates RM, Beck PL, Buret AG: Giardia duodenalis cathepsin B proteases degrade intestinal epithelial interleukin-8 and attenuate interleukin-8-induced neutrophil chemotaxis. Infect Immun 2014, 82:2772-87.

\section{FlOOOPrime}

RECOMMENDED

104. Cotton JA, Motta JP, Schenck LP, Hirota SA, Beck PL, Buret AG: Giardia duodenalis infection reduces granulocyte infiltration in an in vivo model of bacterial toxin-Induced colitis and 
attenuates inflammation in human intestinal tissue. PLoS One 2014, 9:e 109087

105. Koh WH, Geurden T, Paget T, O'Handley R, Steuar RF, Thompson RCA, Buret AG. Giardia duodenalis assemblagespecific induction of apoptosis and tight junction disruption in human intestinal epithelial cells: effects of mixed infections. J Parasitol 2013, 99:353-8.

106. Tysnes KR, Robertson LJ: Investigation of effects of Giardia duodenalis on transcellular and paracellular transport in enterocytes using in vitro Ussing chamber experiments. Parasitology 2015, 142:691-7.

107. Li W, Saraiya AA, Wang CC: Experimental verification of the identity of variant-specific surface proteins in Giardia lamblia trophozoites. MBio 2013, 4:e0032I-I3.

108. Emery SJ, van Sluyter S, Haynes PA, Proteomic analysis in Giardia duodenalis yields insights into strain virulence and antigenic variation. Proteomics 2014, I4:2523-34.

109. Touz MC, Rópolo AS, Rivero MR, Vranych CV, Conrad JT, Svard SG, Nash TE: Arginine deiminase has multiple regulatory roles in the biology of Giardia lamblia. J Cell Sci 2008, I 2 I:2930-8.

I I0. Das S, Schteingart CD, Hofmann AF, Reiner DS, Aley SB, Gillin FD: Giardia lamblia: evidence for carrier-mediated uptake and release of conjugated bile acids. Exp Parasitol 1997, 87:| 33-4I.

I I I. Erlandsen S: Reduction in fecal excretion of Giardia cysts: effect of cholestasis and diet. J Parasitol 2005, 91:|482-4.

II2. de la Guardia RD, Lopez MB, Burgos M, Osuna A: Purification and characterization of a protein capable of binding to fatty acids and bile salts in Giardia lamblia. J Parasitol 201 I, 97:642-47.

I I3. Wampfler PB, Tosevski V, Nanni P, Spycher C, Hehl AB: Proteomics of secretory and endocytic organelles in Giardia Iamblia. PLOS One 2014, 9:e94089.

II4. Woessner DJ, Dawson SC: The Giardia median body protein is a ventral disc protein that is critical for maintaining a domed disc conformation during attachment. Eukaryot Cell 2012, I I:292-30|

I15. Schwartz CL, Heumann JM, Dawson SC, Hoenger A: A detailed, hierarchical study of Giardia lamblia's ventral disc reveals novel microtubule-associated protein complexes. PLoS One 2012, 7:e43783.

I16. Lenaghan SC, Davis CA, Henson WR, Zhang Z, Zhang M: Highspeed microscopic imaging of flagella motility and swimming in Giardia lamblia trophozoites. Proc Nat Acad Sci 20I I, I 08:E55I.

\section{FlOOOPrime
RECOMMENDED}

I17. Stadelmann B, Merino MC, Persson L, Svärd SG: Arginine consumption by the intestinal parasite Giardia intestinalis reduces proliferation of intestinal epithelial cells. PLoS One 2012, 7:e45325

\section{FlOOOPrime}

\section{RECOMMENDED}

I I8. Ventura LL, Oliveira DR, Viana JC, Santos JF, Caliari MV, Gomes MA: Impact of protein malnutrition on histological parameters of experimentally infected animals with Giardia lamblia. Exp Parasitol 2013, 133:39|-5.

I 19. Eckmann L, Laurent F, Langford TD, Hetsko ML, Smith JR, Kagnoff MF, Gillin FD: Nitric oxide production by human intestinal epithelial cells and competition for arginine as potential determinants of host defense against the lumen-dwelling pathogen Giardia Iamblia. J Immunol 2000, I 64:|478-87.

120. Stadelmann B, Hanevik K, Andersson MK, Bruserud O, Svärd SG: The role of arginine and arginine-metabolizing enzymes during Giardia - host cell interactions in vitro. BMC Microbiol 2013, I3:256

121. Azevedo OG, Bolick DT, Roche JK, Pinkerton RF, Lima AAM, Vitek MP, Warren CA, Oriá RB, Guerrant RL: Apolipoprotein E plays a key role against cryptosporidial infection in transgenic undernourished mice. PLoS One 2014, 9:e89562.
122. Oriá RB, Patrick PD, Oriá MO, Lorntz B, Thompson MR, Azevedo OGR, Lobo RNB, Pinkerton RF, Guerrant RL, Lima AAM: ApoE polymorphisms and diarrheal outcomes in Brazilian shanty town children. Braz J Med Biol Res 2010, 43:249-56.

123. Mitter SS, Oriá RB, Kvalsund MP, Pamplona $P$, Joventino ES, Mota RMS, Gonçalves DC, Patrick PD, Guerrant RL, Lima AA: Apolipoprotein E4 influences growth and cognitive responses to micronutrient supplementation in shantytown children from northeast Brazil. Clinics (Sao Paulo) 2012, 67: I I-8.

124. Yahya RS, Awad SI, Elgayar EK, Elborii H, Ragab A, Al-Sawah GA: Impact of apolipoprotein E4 on development and cognitive function in Giardia-infected children. Internet J Parasit Dis 2009, 4.

125. Haque R, Snider C, Liu Y, Ma JZ, Liu L, Nayak U, Mychaleckyj JC, Korpe P, Mondal D, Kabir M, Alam M, Pallansch M, Oberste MS, Weldon W, Kirkpatrick BD, Petri WA: Oral polio vaccine response in breast fed infants with malnutrition and diarrhea. Vaccine 2014, 32:478-82.

126. Costa LB, Noronha FJ, Roche JK, Sevilleja JE, Warren CA, Oriá RB, Lima A, Guerrant RL: Novel in vitro and in vivo models and potential new therapeutics to break the vicious cycle of Cryptosporidium infection and malnutrition. J Infect Dis 2012, 205: |464-7|

127. Coutinho BP, Oriá RB, Vieira CM, Sevilleja JEAD, Warren CA Maciel JG, Thompson MR, Pinkerton RC, Lima AAM, Guerrant RL: Cryptosporidium infection causes undernutrition and, conversely, weanling undernutrition intensifies infection. J Parasitol 2008, 94:1225-32.

128. Costa LB, JohnBull EA, Reeves JT, Sevilleja JE, Freire RS, Hoffman PS, Lima AAM, Oriá RB, Roche JK, Guerrant RL, Warren CA: Cryptosporidium-malnutrition interactions: mucosal disruption, cytokines, and TLR signaling in a weaned murine model. J Parasitol 201 I, 97: I I |3-20.

129. Bolick DT, Roche JK, Hontecillas R, Bassaganya-Riera J, Nataro JP, Guerrant RL: Enteroaggregative Escherichia coli strain in a novel weaned mouse model: exacerbation by malnutrition, biofilm as a virulence factor and treatment by nitazoxanide. J Med Microbiol 2013, 62:896-905.

130. Iñigo-Figueroa G, Méndez-Estrada RO, Quihui-Cota L, VelásquezContreras CA, Garibay-Escobar A, Canett-Romero R, AstiazaránGarcía: Effects of dietary zinc manipulation on growth performance, zinc status and immune response during Giardia lamblia infection: a study in CD-I mice. Nutrients 20I3, 5:3447-60.

I3I. Bolick DT, Kolling GL, Moore JH, de Oliveira LA, Tung K, Philipson C, Viladomiu M, Hontecillas R, Bassaganya-Riera J, Guerrant RL: Zinc deficiency alters host response and pathogen virulence in a mouse model of enteroaggregative Escherichia coli-induced diarrhea. Gut Microbes 2014, 5:618-27.

132. Subramanian S, Huq S, Yatsunenko T, Haque R, Mahfuz M, Alam MA, Benezra A, DeStefano J, Meier M, Muegge BD, Barratt MJ, VanArendonk LG, Zhang Q, Province MA, Petri WA, Ahmed T, Gordon Jl: Persistent gut microbiota immaturity in malnourished Bangladeshi children. Nature 2014, 5 I 0:4I7-2I.

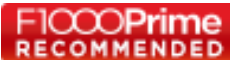

133. Singer SM, Nash TE: The role of normal flora in Giardia lamblia infections in mice. J Infect Dis 2000, I81:1510-2.

\section{FlOOOPrime}

RECOMMENDED

134. Morken MH, Nysaeter G, Strand EA, Hausken T, Berstad A: Lactulose breath test results in patients with persistent abdominal symptoms following Giardia lamblia infection. Scand J Gastroenterol 2008, 43:|4|-5.

135. Torres MF, Uetanabaro AP, Costa AF, Alves CA, Faria LM, Bambirra EA, Penna FJ, Vieira EC, Nicoli JR: Influence of bacteria from the duodenal microbiota of patients with symptomatic giardiasis on the pathogenicity of Giardia duodenalis in gnotoxenic mice. J Med Microbiol 2000, 49:209-I5.

I36. Naess H, Nyland M, Hausken T, Follestad I, Nyland HI: Chronic fatigue syndrome after Giardia enteritis: clinical characteristics, 
disability and long-term sickness absence. BMC Gastroenterol 2012, I 2:13.

137. Mørch K, Hanevik K, Rortveit G, Wensaas KA, Eide GE, Hausken T, Langeland N: Severity of Giardia infection associated with postinfectious fatigue and abdominal symptoms two years after. BMC Infect Dis 2009, 9:206.

138. Fisher BS, Estraño CE, Cole JA: Modeling long-term host cellGiardia lamblia interactions in an in vitro co-culture system. PLoS One 2013, 8:e8II04.

139. Mastronicola D, Falabella M, Testa F, Pucillo LP, Teixeira M, Sarti P, Saraiva LM, Giuffré, A: Functional characterization of peroxiredoxins from the human protozoan parasite Giardia intestinalis. PLoS Negl Trop Dis 2014, 8:e2631.

140. Ferella M, Davids BJ, Cipriano MJ, Birkeland SR, Palm D, Gillin FD, McCarthur AG, Svärd $S$ : Gene expression changes during Giardia-host cell interactions in serum-free medium. Mol Biochem Parasitol 2014, 197:21-3.

14I. Humen MA, De Antoni GL, Benyacoub J, Costas ME, Cardozo MI, Kozubsky L, Saudan KY, Boenzli-Bruand A, Blum S, Schiffrin EJ, Pérez PF: Lactobacillus johnsonii Lal antagonizes Giardia intestinalis in vivo. Infect Immun 2005, 73:1265-9.

\section{FlOOOPrime \\ RECOMMENDED}

142. Shukla G, Sidhu RK, Verma A: Restoration of anthropometric, biochemical and histopathological alterations by Lactobacillus casei supplementation in Giardia intestinalis infected renourished BALB/c mice. Antonie Van Leeuwenhoek 20I2, 102:6I-72.

143. Goyal N, Shukla G: Probiotic Lactobacillus rhamnosus GG modulates the mucosal immune response in Giardia intestinalis-infected BALB/c mice. Dig Dis Sci 20|3, 58:I2|8-25.

144. Goyal N, Rishi P, Shukla G: Lactobacillus rhamnosus GG antagonizes Giardia intestinalis induced oxidative stress and intestinal disaccharidases: an experimental study. World J Microbiol Biotechnol 2013, 29:1049-57.

145. Pérez PF, Minnaard J, Rouvet M, Knabenhans C, Brassart D, De Antoni GL, Schiffrin EJ: Inhibition of Giardia intestinalis by extracellular factors from Lactobacilli: an in vitro study. Appl Environ Microbiol 200I, 67:5037-42.

146. Amer El, Mossallam SF, Mahrous H: Therapeutic enhancement of newly derived bacteriocins against Giardia lamblia. Exp Parasitol $2014,146: 52-63$

147. Franco MC, Golowczyc MA, De Antoni GL, Pérez PF, Humen M, Serradell Mde L: Administration of kefir-fermented milk protects mice against Giardia intestinalis infection. J Med Microbiol 2013, 62:1815-22.

148. Obendorf J, Renner Viveros P, Fehlings M, Klotz C, Aebischer T, Ignatius R: Increased expression of CD25, CD83, and CD86, and secretion of IL- I2, IL-23, and IL- 10 by human dendritic cells incubated in the presence of Toll-like receptor 2 ligands and Giardia duodenalis. Parasit Vectors 2013, 6:317.

149. Kamda JD, Singer SM: Phosphoinositide 3-kinase-dependent inhibition of dendritic cell interleukin-12 production by Giardia lamblia. Infect Immun 2009, 77:685-93.

150. Grit GH, Devriendt B, Van Coppernolle S, Geurden T, Hope J, Vercruysse J, Cox E, Geldhof P, Claerebout E: Giardia duodenalis stimulates partial maturation of bovine dendritic cells associated with altered cytokine secretion and induction of T-cell proliferation. Parasite Immunol 20I4, 36:157-69.

15I. Mukherjee AK, Chowdhury P, Rajendran K, Nozaki T, Ganguly S: Association between Giardia duodenalis and coinfection with other diarrhea-causing pathogens in India. Biomed Res Int 2014, 2014:786480.

\section{FlOOOPrime}

152. Sulis G, Villanacci V, Missale G, Salemme M, Castelli F, Caligaris S: Whipple's disease concomitant with candida esophagitis and subsequent Giardia lamblia coinfection. Eur J Gastroenterol Hepatol 2014, 26: II8I-5.
153. Vasco G, Trueba G, Atherton R, Calvopiña M, Cevallos W Andrade $T$, Eguiguren $M$, Eisenberg JNS: Identifying etiological agents causing diarrhea in low income Ecuadorian communities. Am J Trop Med Hyg 2014, $91: 563-9$.

154. Cotton JA, Beatty JK, Buret AG: Host parasite interactions and pathophysiology in Giardia infections. Int J Parasitol 201I, 41:925-33.

\section{FlOOOPrime} RECOMMENDED

155. Roxström-Lindquist K, Ringqvist E, Palm D, Svärd S: Giardia lambliainduced changes in gene expression in differentiated Caco-2 human intestinal epithelial cells. Infect Immun 2005, 73:8204-8.

156. Kamda JD, Nash TE, Singer SM: Giardia duodenalis: dendritic cell defects in IL-6 deficient mice contribute to susceptibility to intestinal infection. Exp Parasitol 2012, 130:288-91.

157. Zhou P, Li E, Zhu N, Robertson J, Nash T, Singer SM: Role of interleukin-6 in the control of acute and chronic Giardia lamblia infections in mice. Infect Immun 2003, 71:1566-8.

158. Li E, Zhou P, Petrin Z, Singer SM: Mast cell-dependent control of Giardia lamblia infections in mice. Infect Immun 2004, 72:6642-9.

159. Tako EA, Hassimi MF, Li E, Singer SM: Transcriptomic analysis of the host response to Giardia duodenalis infection reveals redundant mechanisms for parasite control. MBio 2013, 4: e00660-13.

160. Li E, Zhou P, Singer SM: Neuronal nitric oxide synthase is necessary for elimination of Giardia lamblia infections in mice. J Immunol 2006, I76:5I6-2I.

16I. Andersen YS, Gillin FD, Eckmann L: Adaptive immunity-dependent intestinal hypermotility contributes to host defense against Giardia spp. Infect Immun 2006, 74:2473-6.

162. Ljungström I, Castor B: Immune response to Giardia lamblia in a water-borne outbreak of giardiasis in Sweden. J Med Microbiol 1992, 36:347-52.

163. Jiménez JC, Fontaine J, Creusy C, Fleurisse L, Grzych JM, Capron M, Dei-Cas E: Antibody and cytokine responses to Giardia excretory/secretory proteins in Giardia intestinalis-infected BALB/c mice. Parasitol Res 2014, I 13:2709-18.

164. Ebert EC: Giardia induces proliferation and interferon gamma production by intestinal lymphocytes. Gut 1999, 44:342-6.

165. Hanevik K, Kristoffersen E, Svard S, Bruserud O, Ringqvist E, Sørnes S, Langeland N: Human cellular immune response against Giardia lamblia 5 years after acute giardiasis. J Infect Dis 20I I, 204: 1779-86.

\section{FlOOOPrime} RECOMMENDED

166. Isaac-Renton JL, Lewis LF, Ong CS, Nulsen MF: A second community outbreak of waterborne giardiasis in Canada and serological investigation of patients. Trans $R$ Soc Trop Med Hyg 1994, 88:395-9.

167. Ament ME, Rubin CE: Relation of giardiasis to abnormal intestinal structure and function in gastrointestinal immunodeficiency syndromes. Gastroenterology 1972, 62:216-26.

168. Perlmutter DH, Leichtner AM, Goldman H, Winter HS: Chronic diarrhea associated with hypogammaglobulinemia and enteropathy in infants and children. Dig Dis Sci 1985, 30: I 1 49-55.

169. Oksenhendler E, Gérard L, Fieschi C, Malphettes M, Mouillot G, Jaussaud R, Viallard JF, Gardembas M, Galicier L, Schleinitz N, Suarez F, Soulas-Sprauel P, Hachulla E, Jaccard A, Gardeur A, Théodorou I, Rabian C, Debré P; DEFI Study Group: Infections in 252 patients with common variable immunodeficiency. Clin Infect Dis 2008, 15:1547-54.

170. Zinneman HH, Kaplan AP: The association of giardiasis with reduced intestinal secretory immunoglobulin $\mathbf{A}$. Am J Dig Dis 1972, 17:793-7.

171. Char S, Cevallos AM, Yamson P, Sullivan PB, Neale G, Farthing MJ: Impaired IgA response to Giardia heat shock antigen in children with persistent diarrhoea and giardiasis. Gut 1993, 34:38-40. 
172. Langford TD, Housley MP, Boes M, Chen J, Kagnoff MF, Gillin FD, Eckmann L: Central Importance of Immunoglobulin A in Host Defense against Giardia spp. Infect Immun 2002, 70:I I-I8.

\section{FlOOOPrime}

\section{RECOMMENDED}

173. Davids BJ, Palm JE, Housley MP, Smith JR, Andersen YS, Martin MG, Hendrickson BA, Johansen FE, Svärd SG, Gillin FD, Eckmann L: Polymeric immunoglobulin receptor in intestinal immune defense against the lumen-dwelling protozoan parasite Giardia. J Immunol 2006, I77:628I-90.

174. Solaymani-Mohammadi S, Singer S: Regulation of Intestinal Epithelial Cell Cytoskeletal Remodeling by Cellular Immunity Following Gut Infection. Mucosal Immunol 2013, 6:369-78.

175. Buret A, Gall DG, Olson ME. Growth, activities of enzymes in the small intestine, and ultrastructure of microvillous border in gerbils infected with Giardia duodenalis. Parasitol Res 1991, 77:109-14.

176. Long KZ, Rosado JL, Santos JI, Haas M, Mamun AA, DuPont HL, Nanthakumar NN, Estrada-Garcia T: Associations between mucosal innate and adaptive immune responses and resolution of diarrheal pathogen infections. Infect Immun 2010, 78: $1221-8$.

177. Anderson KA, Brooks AS, Morrison AL, Reid-Smith RJ, Martin SW, Benn DM, Peregrine AS: Impact of Giardia vaccination on asymptomatic Giardia infections in dogs at a research facility. Can Vet J 2004, 45:924-30.

178. Korpe PS, Liu Y, Siddique A, Kabir M, Ralston K, Ma JZ, Haque R, Petri WA: Breast milk parasite-specific antibodies and protection from amebiasis and cryptosporidiosis in Bangladeshi infants: a prospective cohort study. Clin Infect Dis 2013, 56:988-92.

179. Rivero FD, Saura A, Prucca CG, Carranza PG, Torri A, Lujan HD: Disruption of antigenic variation is crucial for effective parasite vaccine. Nature Medicine 2010, 16:55I-7.

\section{FlOOOPrime
RECOMMENDED}

180. Jenikova G, Hruz P, Andersson KM, Tejman-Yarden N, Ferreira PCD, Andersen YS, Davids BJ, Gillin FD, Svärd SG, Curtiss R, Eckmann L: $\alpha I$-giardin based live heterologous vaccine protects against Giardia lamblia infection in a murine model. Vaccine 2011, 29:9529-37. 